\title{
Carbon Sequestration Potentials of Man-made Grasslands under Different Pattern of Plantation Stands in West Bandung Regency, Indonesia
}

\author{
Annas Dwitri Malik ${ }^{1,2 *}$, Maulida Isfahani Nurillah ${ }^{3}$, Parikesit ${ }^{1,2,3}$, Susanti Withaningsih ${ }^{1,2,3}$, Ratna Wingit $^{4}$ \\ ${ }^{1}$ Sustainability Science Program, Postgraduate School, Universitas Padjadjaran, Indonesia \\ ${ }^{2}$ Center for Environment and Sustainability Science, Universitas Padjadjaran, Indonesia \\ ${ }^{3}$ Department of Biology, Faculty of Mathematic and Natural Sciences, Universitas Padjadjaran, Indonesia \\ ${ }^{4}$ PT Bio Farma, Indonesia
}

\begin{abstract}
Alternatives of vegetations to store carbon need to be encouraged considering that forests are threatened by widespread destructions. One such vegetation is grasslands which have the potential for carbon storage and to reduce $\mathrm{CO}_{2}$ concentration in the atmosphere. At present, many enterprises have designed grasslands for many purposes. Grasslands at Cikalong Wetan and Little Farmers, West Bandung Regency were established under different pattern of plantation stands. The purpose of this research was to study the potential of carbon stock in grassland vegetation at these locations. Based on RaCSA method, the tree biomass was determined by nondestructive collection of density and basal area of trees, then calculated by an allometric equation. The ground cover biomass was determined by destructive collection of grass and roots. Total measured biomass was multiplied by $46 \%$ to obtain carbon storage. Based on the results, the potential of carbon stock in Little Farmers grassland $\left(159,540\right.$ ton ha $\left.{ }^{-1}\right)$ is higher than in Cikalong Wetan $\left(14,482\right.$ ton $\left.\mathrm{ha}^{-1}\right)$. Carbon stored in tree biomass gives the highest contribution to overall carbon stock potential in Little Farmers (94.84\%) while carbon stored in below-ground understorey biomass gives the highest contribution in Cikalong Wetan $(52.13 \%)$. Different management of grasslands and pattern of plantation stands resulting a different contribution of carbon stock in every carbon pool. In order to maintain the carbon sequestration potentials of these locations, an agroforestry management such as agri-silviculture need to be encouraged. This study gives a comparison of the carbon sequestration potentials between two man-made grassland ecosystems. For many enterprises this study will aid in a management planning of manmade grassland in terms of ecosystem services, that is carbon sequestration.
\end{abstract}

\section{Introduction}

Although natural terrestrial ecosystems give $\sim 25 \%$ to $\mathrm{CO} 2$ emmisons sequestration, the sustainability of this key ecosystem is under question [1]. Forest destruction, climate change, and global warming cause a decrease in forest area, which means that they can reduce the forests potential which is expected to store carbon at least 10 times greater than other types of vegetation [2]. Beside of that, anthropogenic factors which are responsible to forest destruction is still inevitable. FAO recorded that many large scale commercial agriculture and subsistence is responsible to $73 \%$ of this planet's deforestation [3]. A similar situation also happens in Indonesia. At the moment, carbon stored in primary highland forests in Indonesia is 103.16 tons/ha with the continued forest destruction, in 2015 to 2016 the deforestation was 0.63 million hectares and in 2017, the extent of deforestation stood at 0.48 million hectares with the most significant deforestation occurred in secondary forests both in and outside of the Forest Area [4].

With this widespread forest destruction, other types of ecosystem to store carbon need to be encouraged. Grassland ecosystems, which cover of the 40 percent terrestrial ecosystem become important because they widely distributed about 3.5 billion hectares of land cover in this planet, representing 26 percent of all land use and 70 percent of agricultural land in the world, and contributing to 20 percent of belowground carbon $[5,6]$ This one type of land uses play an important role in biodiversity as well as carbon sequestration and climate regulation [5]. As main forage resource for livestock, grasslands are important for human well-being in many regions [7]. In pasture areas, the amount of grassland carbon stocks determine herbivore carrying capacity and forage availability $[8,9]$. Unlike in forests, carbon stored in grasslands are dominantly in herbaceous vegetation biomasses, so that the aboveground vegetations of a grassland give a small proportion in carbon sequestration [10]. Even though the rate of carbon sequestration of grasslands are lower than primary and secondary forests, potential of carbon sequestration of grasslands are still can be considered in order to reduce the $\mathrm{CO} 2$ emmissions in the atmosphere because of its large proportion of coverage in the terrestrial ecosystems [6].

Unfortunately, due land use change large and climate variability, areas of grasslands are endangered and reduced in a large portion [8,11]. Along with this phenomenon, many non-permanent grasslands are established for various purposes, generally for animal feed (grazing area). Grazed pastures may sequester more $\mathrm{C}$ than grasslands used for silage or hayproduction, due to the recycling of organic matter and nutrients from faeces and plant residues [12]. However, continuous

\footnotetext{
*Corresponding author: annas.dm27@gmail.com
} 
heavy grazing would be detrimental to the growth of the herbaceous plants which in turn may lead to the depletion of aboveground and soil carbon stocks [13]. Therefore, an effective grazing management is needed in order to return carbon released from the soil and become carbon sequences [14].

Many enterprises are competing each other in establishing an effective man-made grassland management. One of which is PT Bio Farma, who established a 7 ha man-made grassland for recreational, and educational purposes in Little Farmers, Cisarua, Indonesia [15]. By this year, the enterprise has expanded the grazing area to Cikalong Wetan, Indonesia. As those two areas are established in different climate conditions, and a typical fast-growing grass is cultivated under different plantation stands, there is a need to compare the carbon sequestration potentials of these two locations..

\section{Material and Methods}

The determination of sample plots is based on RaCSA (Rapid Carbon Stock Appraisal) method [16], the determination of sample plots was undertaken by assuming an area of land as a research plot. All individual trees were measured in one area of Little Farmers grassland. Then for the sampling of grass plants and roots, 30 sub-plots of $1 \mathrm{~m} \mathrm{x} 1 \mathrm{~m}$ were placed randomly. Little Farmers had an area of 73,005.13 $\mathrm{m}^{2}$ , meanwhile Cikalong Wetan had an area of 1,1704 ha. The delineated area is shown in Figure 1.

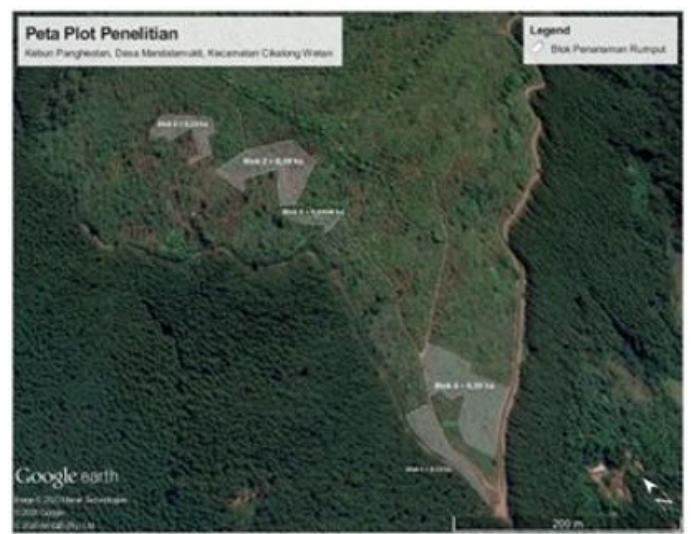

(a)

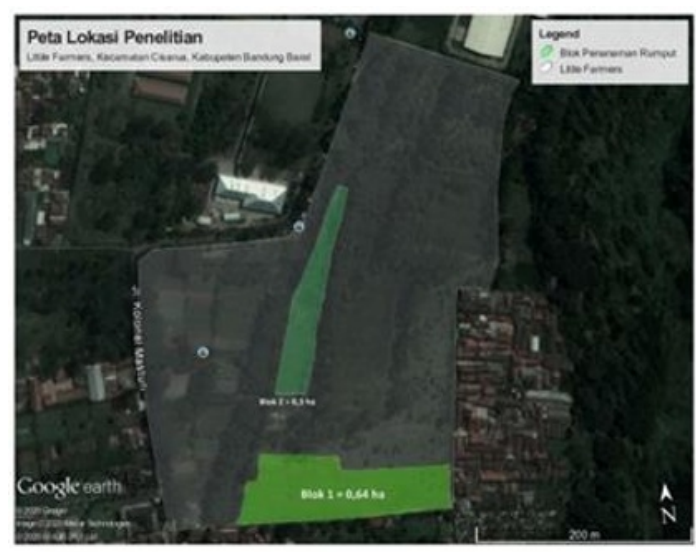

(b)
Figure 1 (a) Research area in Cikalong Wetan, (b) Research area in Little Farmers Cisarua

\subsection{The Tree Biomass Measurement}

The tree biomass measurement is conducted undestructively by recording the scientific name of all trees and measuring DBH (Diameter at Breast Height), and tree height (Hairiah et al., 2011). Trunk diameter measurement is ilustrated by Figure 2 below.

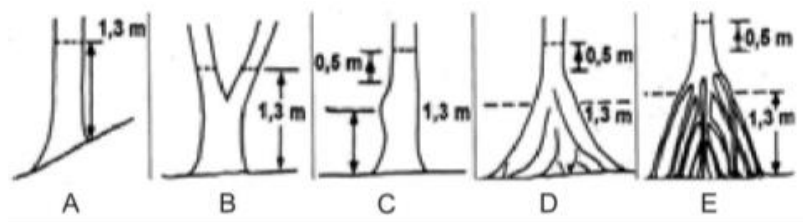

Figure 2. Schematics on how to determine the height measurements of tree trunks with irregular shapes [17].

\subsection{The Measurement of Cover Grond Biomass (Grasses)}

Measurement of understorey biomass was carried out by destructive methods. The plants sampled were all herbs and grasses. Sampling was done by cutting the above ground part of the plant in the sub-plot. Samples were placed in plastic bags, labeled according to the sub-plot code, and weighed to obtain the total wet weight. Furthermore, 100-300 grams of sub-samples are taken from the sample and reweighed to obtain sub-sample wet weight. If the sample biomass is $<100 \mathrm{~g}$, the entire sample is weighed as a sub-sample. These sub-samples were then dried in an oven at $80^{\circ} \mathrm{C}$ for 48 hours. After that, the sub-sample was weighed and the data was recorded in the observation sheet [16].

\subsection{The Measurement of Root Biomass}

Measurement of grassroots biomass was carried out destructively. The roots of the grass samples were separated from the leaves and stems, then put in a plastic bag and weighed to obtain the total wet weight. Thereafter, 100-300 $\mathrm{g}$ of sample are separated and weighed as sub-sample wet weight. As with the measurement of understorey biomass, all samples are weighed back into sub-samples if the sample biomass is $<100 \mathrm{~g}$. The sub-sample biomass was then dried in an oven at $80^{\circ} \mathrm{C}$ for $2 \times 24$ hours. The dry weight of the sub-sample biomass was weighted and the data was recorded in an observation sheet [16].

\subsection{The Tree Biomass Analysis}

Tree biomass estimation can be calculated using allometric equations. This equation is obtained from tree species data and various physical parameters such as $\mathrm{DBH}$, tree height, and wood density obtained from the Global Wood Density Database [18,19]. These parameters were analyzed using the allometric equation developed by [20] as follows : 


$$
A G B=0,0509 \times \rho D^{2} H
$$

with:

Biomass $=$ aboveground tree biomass $(\mathrm{kg} /$ individual of tree)

$\mathrm{D}=$ diameter of tree trunk $(\mathrm{cm})$

$\mathrm{H}=$ tree height $(\mathrm{m})$

$\pi=\operatorname{wood}$ density $(\mathrm{g} / \mathrm{cm})$

\subsection{The Cover Ground and Grassroot Biomass Analysis}

Calculation of understorey and root biomass can be caried out by calculating the total dry weight per subplot area $(1 \mathrm{~m} 2)$ with the following formula [16].

$$
\text { Total } D=\frac{D_{\text {sub-sample }}}{W_{\text {sub-sample }}} \times \text { Total } W
$$

with:

$\mathrm{D}=$ Dry weight

$\mathrm{W}=$ Wet weight

\section{Result}

\subsection{Average of Carbon Storage in Cikalong Wetan}

Tree biomass and carbon stock obtained from trees in Cikalong Wetan were 6.169 tonnes ha-1 and 2.837 tonnes ha-1, respectively, with an average value for each individual of 0.325 tonnes ha- 1 and 0.149 tonnes ha-1. The five tree species with the highest carbon stock can be seen in Table 1. A comparison of the carbon storage potential of the five tree species can be seen in Figure 3.

Table 1 Five tree species with the highest carbon storage in Cikalong Wetan

\begin{tabular}{|l|c|c|}
\hline \multicolumn{1}{|c|}{ Species } & $\begin{array}{c}\text { Biomass } \\
\text { (tonnes ha }^{-1} \text { ) }\end{array}$ & $\begin{array}{c}\text { Carbon } \\
\text { (tonnes ha-1 }^{-1}\end{array}$ \\
\hline $\begin{array}{l}\text { White Teak } \\
\text { (Gmelina } \\
\text { arborea) }\end{array}$ & 2,979 & 1,370 \\
\hline $\begin{array}{l}\text { Pine } \\
\text { (Pinus } \\
\text { merkusii) }\end{array}$ & 0,605 & 0,278 \\
\hline $\begin{array}{l}\text { Ki Sireum } \\
\text { (Syzygium } \\
\text { zeylanicum })\end{array}$ & 0,486 & 0,224 \\
\hline $\begin{array}{l}\text { Weeping } \\
\text { Paperbag } \\
\text { (Melaleuca } \\
\text { leucadendra) }\end{array}$ & 0,385 & 0,177 \\
\hline $\begin{array}{l}\text { Red Lucky } \\
\text { Seed } \\
\text { (Adenanthera } \\
\text { pavonina) }\end{array}$ & 0,377 & 0,173 \\
\hline
\end{tabular}

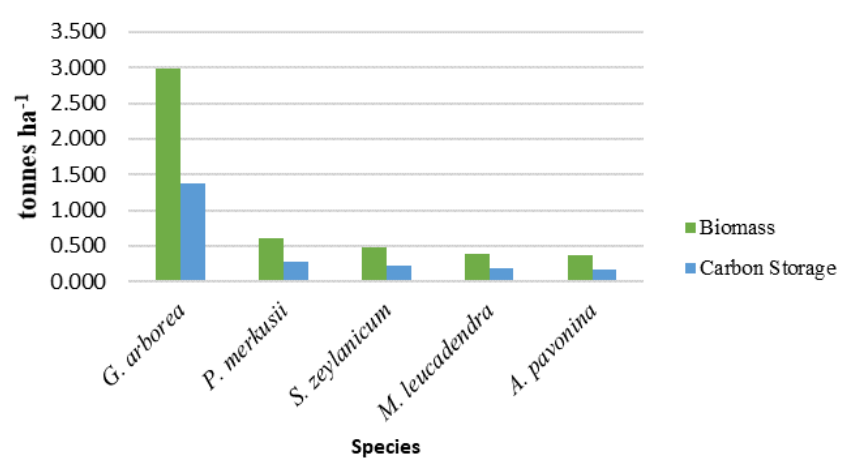

Figure 3 Comparison of potential carbon storage in five tree species with the highest carbon stocks in Cikalong Wetan

Biomass and carbon stock of understorey (grass) and roots at the Cikalong Wetan can be seen in Table 2. The carbon stored below the ground $\left(7,549\right.$ tonnes $\left.\mathrm{ha}^{-1}\right)$ is greater in value than the carbon stored above the ground $\left(4,096\right.$ tonnes $\left.\mathrm{h}^{-1}\right)$.

Table 2 Calculation result of carbon storage of understorey in Cikalong Wetan

\begin{tabular}{|l|l|l|l|l|}
\hline & $\begin{array}{c}\text { Biomass } \\
\text { (ton) }\end{array}$ & $\begin{array}{c}\text { Biomass } \\
\text { (ton ha } \mathbf{~ h}^{-1} \text { ) }\end{array}$ & $\begin{array}{c}\text { Carbon } \\
\text { (ton) }\end{array}$ & $\begin{array}{c}\text { Carbon } \\
\text { (ton ha }^{-1} \text { ) }\end{array}$ \\
\hline $\begin{array}{l}\text { DW } \\
\text { (AGB) }\end{array}$ & 0.0089 & 8.9035 & 0.0041 & 4.096 \\
\hline $\begin{array}{l}\text { DW } \\
\text { (BGB) }\end{array}$ & 0.0164 & 16.4117 & 0.0075 & 7.549 \\
\hline Total & & 25.3152 & & 11.645 \\
\hline
\end{tabular}

Note : $\quad \mathrm{DW}=$ dry weight ; $\mathrm{AGB}=$ above-ground biomass; $\mathrm{BGB}=$ below-ground biomass

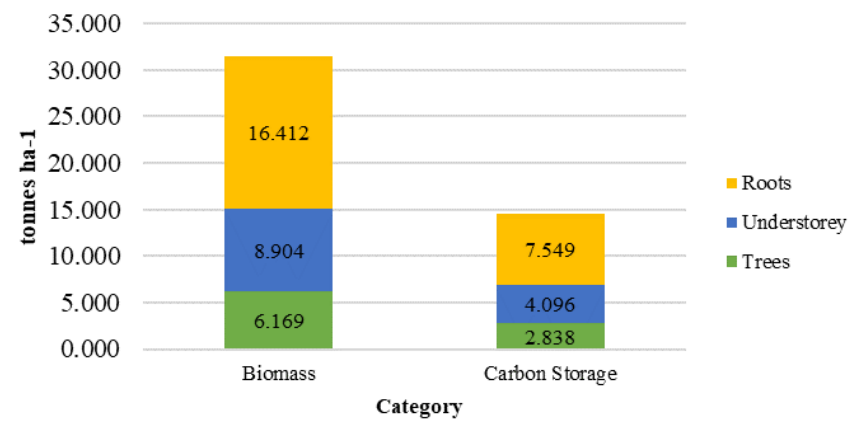

Figure 4 Total of Biomass and Carbon Storage per area in Cikalong Wetan

Graphs of total biomass and carbon stock in each carbon pool (tree biomass, understorey biomass, and root biomass) in the Cikalong Wetan research can be seen in Figure 4. The total measured biomass is 31.485 tonnes $\mathrm{ha}^{-1}$ with an estimated carbon stored of 14.483 tonnes $\mathrm{ha}^{-1}$. From the graph, it can be seen that plant biomass and carbon stocks are mostly stored in roots, followed by understorey and trees. 


\subsection{Average of Carbon Storage in Little Farmers, Cisarua}

The biomass and carbon stored in trees were 328,933 ton ha-1 and 151,309 tonnes ha-1 respectively, with an average of 9,137 tonnes ha-1 and 4,203 tonnes ha-1. Table 3 shows the five tree species with the highest amount of carbon stock and a comparison of their carbon storage potential can be seen in Figure 5.

Table 3 Five tree species with the highest carbon storage in Little Farmers, Cisarua

\begin{tabular}{|c|c|c|}
\hline Spesies & $\begin{array}{c}\text { Biomasss } \\
\text { (ton ha-1) }\end{array}$ & $\begin{array}{c}\text { Carbon } \\
\text { (ton } \mathbf{h a}^{-1} \text { ) }\end{array}$ \\
\hline $\begin{array}{c}\text { Eucalyptus } \\
\text { (Eucalyptus } \\
\text { sp.) }\end{array}$ & 280,985 & 129,253 \\
\hline $\begin{array}{c}\text { Amboyna Pine } \\
\text { (Agathis } \\
\text { dammara) }\end{array}$ & 30,638 & 14,093 \\
\hline $\begin{array}{c}\text { December } \\
\text { Tree } \\
\text { (Erythrina } \\
\text { subumbrans })\end{array}$ & 5,007 & 2,303 \\
\hline $\begin{array}{c}\text { Palm } \\
\text { (Roystonea } \\
\text { regia) }\end{array}$ & 2,401 & 1,104 \\
\hline $\begin{array}{c}\text { Sea Mango } \\
\text { (Cerbera } \\
\text { manghas) }\end{array}$ & 1,667 & 0,767 \\
\hline
\end{tabular}

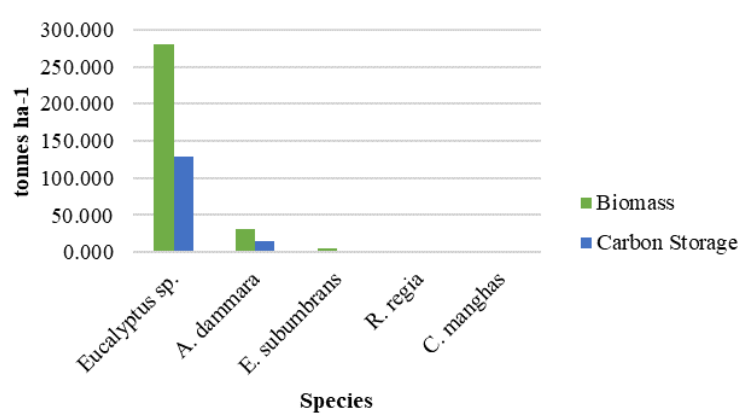

Figure 5 Comparison of potential carbon storage in five tree species with the highest carbon stocks in Little Farmers, Cisarua

Biomass and the potential carbon stored in understorey and grass biomass can be seen in Table 4 . The total carbon stored in both aboveground biomass and belowground biomass is 8,231 tonnes $\mathrm{kg}-1$. The carbon stored below the soil surface $\left(7,754\right.$ tonnes ha $\left.{ }^{-1}\right)$ is greater in value than the carbon stored above ground (0.477 tonnes ha $\left.{ }^{-1}\right)$.

Figure 6 shows a comparison of the total biomass and carbon stock in each carbon pool in Little Farmers. The total biomass measured was 346,827 tonnes ha ${ }^{-1}$ with an estimated carbon stored at 159,540 tonnes ha-1 Most carbon is stored in trees, followed by roots and understorey.
Table 4 Calculation result of carbon storage of understorey in Little Farmers, Cisarua

\begin{tabular}{|l|l|l|l|l|}
\hline & $\begin{array}{c}\text { Biomass } \\
\text { (ton) }\end{array}$ & $\begin{array}{c}\text { Biomass } \\
\left.\text { (ton ha } \mathbf{~}^{-1}\right)\end{array}$ & $\begin{array}{c}\text { Carbon } \\
\text { (ton) }\end{array}$ & $\begin{array}{c}\text { Carbon } \\
\left.\text { (ton ha }^{-1}\right)\end{array}$ \\
\hline $\begin{array}{l}\text { DW } \\
(\mathrm{AGB})\end{array}$ & 0.0016 & 1.0372 & 0.0007 & 0.477 \\
\hline $\begin{array}{l}\text { DW } \\
(\mathrm{BGB})\end{array}$ & 0.0253 & 16.8560 & 0.0116 & 7.754 \\
\hline Total & & 17.8932 & & 8.231 \\
\hline
\end{tabular}

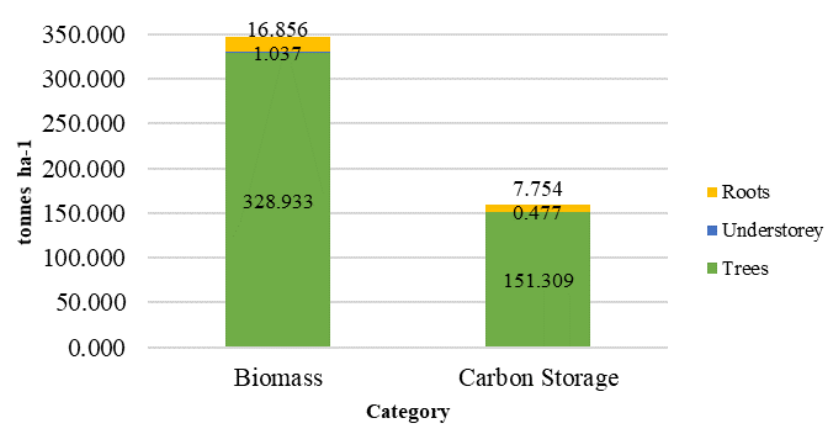

Figure 6 Total of Biomass and Carbon Storage per area in Little Farmers, Cisarua

Comparison of Carbon Storage between Cikalong Wetan and Little Farmers, Cisarua

Potentials of carbon sequestration in every carbon pool in Cikalong Wetan and Little Farmers, Cisarua can be seen in Figure 7

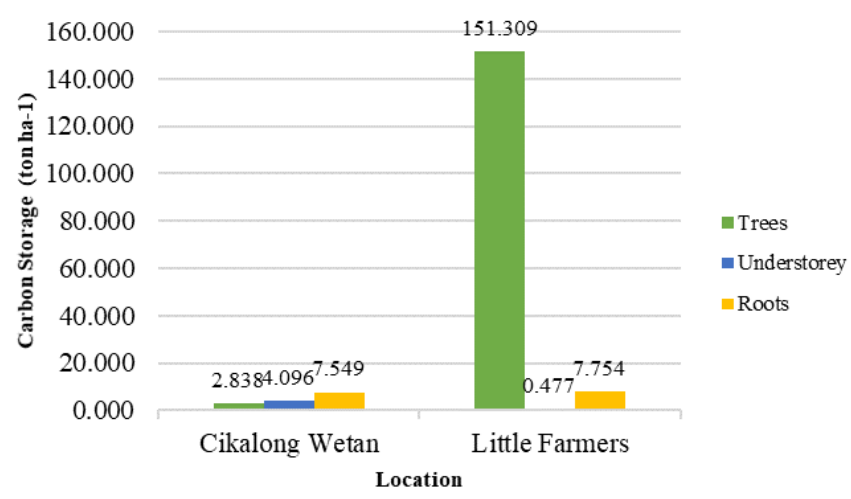

Figure 7 Comparison of Carbon Storage in Cikalong Wetan and Little Farmers, Cisarua

The total carbon stock contained in Cikalong Wetan is 14,482 tonnes $\mathrm{ha}^{-1}$ with the proportion of the constituent biomass of trees, undergrowth and roots, $19.59 \%$; 28.28\%; and 52.13\%, respectively. Little Farmers with a total carbon stock of 159,540 tonnes ha${ }^{1}$ has the composition of the composition of understorey biomass, root biomass, and tree biomass $0.30 \%$; 4.86\%; and $94.84 \%$, respectively. 


\section{Discussion}

\subsection{The Tree with the Highest Potential in Carbon Sequestration}

White Teak (G. arborea) is known to have the highest carbon stock in Cikalong Wetan with a carbon storage potential of 1,370 tonnes ha- 1 . White teak is a type of deciduous plant with rapid growth that has high economic value, so it is widely cultivated in the Southeast Asia region [21]. Based on research conducted by [22]. G. arborea has the potential to absorb carbon effectively because it shows a positive growth response to increased $\mathrm{CO} 2$ during the experiment. The exchange of $\mathrm{CO} 2$ from plants to the atmosphere mainly occurs through the stomata, but the conductance of the stomata will hinder the assimilation of carbon when plants are in excess $\mathrm{CO} 2$ conditions. G. arborea is able to reduce the conductance of these stomata so that photosynthetic activity can be accelerated [23-25]. The rate of photosynthesis is related to carbon assimilation so that species with a fast rate of photosynthesis can be more efficient in the carbon sequestration process.

Eucalyptus have the highest amount of biomass and carbon stock in Little Farmers, Cisarua with a carbon storage potential of 129,253 tonnes ha-1. Eucalyptus is a type of plant that can grow rapidly so that its biomass growth is fast. In addition, eucalyptus has high water requirements so that they can suppress the growth of other plants and reduce the species rihness and diversity in the area [26].

\subsection{The Average of Carbon Stored in Each Carbon Pool}

Graphs of total biomass and carbon stock in each carbon pool (tree biomass, understorey biomass, and root biomass) in the Cikalong Wetan can be seen in Figure 4. Based on the results of data collection, trees in the Cikalong Wetan area have a diameter of no more than $36 \mathrm{~cm}$. Trees with $\mathrm{DBH}<30 \mathrm{~cm}$ have a light density $\left(<0.6 \mathrm{~g} \mathrm{~cm}^{-3}\right)$ to moderate $\left(0.6-0.75 \mathrm{~cm}^{-3}\right)$ [27] so that they affect the number of biomass contained therein. In addition to the density of wood, biomass is also influenced by the photosynthesis process [28]. Tree leaves that are often used as animal feed will reduce the area of leaves per unit of land, thereby reducing the amount of $\mathrm{CO}_{2}$ absorption that will be stored in biomass as carbohydrates.

Trees in Cikalong Wetan store the least amount of carbon in the estimated total carbon storage potential. This is thought to have occurred due to the relatively small basal area of trees in the area. According to [27], basal area of tree has a high correlation with total carbon stock. This is also corresoinding with [29], who reported that the decline in carbon stocks in the Jangkok watershed (Lombok Island) was closely related to a decrease in the number of large trees, reflecting a decrease in basal area of trees after the forest in the area was converted to agriculture. The carbon stored below the soil surface $\left(7,549\right.$ tonnes $\left.\mathrm{ha}^{-1}\right)$ is greater in value than the carbon stored above the ground (4,096 tonnes $\mathrm{ha}^{-1}$ ) in Cikalong Wetan. The low decomposition of root biomass causes an accumulation of organic matter [30]. This carbon accumulation will continue as the plants age [31].Thus, belowground biomass can store more carbon than aboveground biomass.

Graphs of total biomass and carbon stock in each carbon pool in the Little Farmers, Cisarua can be seen in Figure 6. Most carbon are stored in trees, followed by roots and understorey. Agroforestry systems are believed to have better carbon sequestration potential than pasture or plantation. This assumption is based on the idea that combining trees in agricultural land and grasslands will result in greater sequestration of above and below ground carbon [32]. Little Farmers is an agroforestry which is made to meet the needs of animal feed. The land is divided into several plots and planted with types of grass as needed. The grass is routinely harvested after \pm 40 days by taking part of the leaves and leaving the grass roots in order to stimulate new grass growth. This indicates that the above-ground plant biomass (understorey) will continue to be lost and there is carbon released from the land in one cropping cycle ( \pm 40 days). These aboveground biomass carbon has a relatively short age due to removal, cattle feeds, fire, and deteriotation with age [10].

\subsection{Comparison of Carbon Sequestration Potential between Cikalong Wetan and Little Farmers, Cisarua}

The carbon stock in Cikalong Wetan has a different percentage composition from Little Farmers. The trees in Cikalong Wetan store the least amount of carbon in the estimated total carbon storage potential, while the trees in Little Farmers store the most. This is thought to have occurred due to differences in the volume and age of trees and the size of the area. The average stands diameter and height in Cikalong Wetan were relatively lower than the stands in Little Farmers. In addition, the Cikalong Wetan research area is larger than the Little Farmers research area. The larger the area, the greater the divider value for potential carbon storage per hectare.

In both Cikalong Wetan and Little Farmers, the percentage of the constituent root biomass carbon stock was recorded to be greater than that of understorey biomass. As previously explained, the carbon stored in below-ground biomass will continue to increase with increasing plant age. Below-ground biomass will be better protected from disturbance so that carbon can be stored longer [32].

\subsection{Policy Implications of This Study}

In fact, agroforestry has functions both as a carbon source and as a carbon sequester. The agri-silvicultural system (a combination of forest and agricultural commodities) acts as a carbon sequester, while the agrosilvicultural system (a combination of forests, agricultural commodities, and livestock) also acts as a source of greenhouse gases [33]. Based on the description above, the agroforestry system that has been 
implemented in these two locations grasslands needs to be maintained by continuing to maintain the existence of stands. Given the results of this study, it is known that the contribution of stands to carbon sequestration is greater than the contribution of grasses. In order to optimize the potential for carbon storage, land management that can be done is by implementing an agri-silvicultural land management system.

\section{Conclusion}

Based on the results, the potential of carbon stock in Little Farmers $\left(159,540\right.$ tonnes $\left.\mathrm{ha}^{-1}\right)$ is higher than in Cikalong Wetan $(14,482$ tonnes ha-1). Carbon stored in tree biomass gives the highest contribution to overall carbon stock potential in Little Farmers $(94.84 \%)$ while carbon stored in below-ground understorey biomass gives the highest contribution in Cikalong Wetan (52.13 $\%$ ). Different management of grasslands and pattern of plantation stands resulting a different contribution of carbon stock in every carbon pool. In order to maintain the carbon sequestration potentials of these locations, an agroforestry management such as agri-silviculture needs to be encouraged.

\section{Acknowledgment}

The authors would like to thank to PT Bio Farma for their trust to the PUI-PT CESS (Center for Environment and Sustainability Science) Universitas Padjadjaran and ALG (Academic Leadership Grants) Universitas Padjadjaran for conducting the research at Little Farmers Agro Tourism and Cikalong Wetan in order to maintain their commitment to be oriented towards environmental programs which are "beyond compliance"

\section{References}

1. P. Dass, B. Z. Houlton, Y. Wang, and D. Warlind, Environ. Res. Lett. 13, $074027 \quad$ (2018)

2. N. Masripatin, K. G., Gustan P., Wayan S., Chairil A., Ari W., Dyah P., Arief S., Niken S., Mega L., Indartik, Wening W., Saptadi D., Ika H., Heriyanto N.M., Haris S., Ratih D., Dian A., Haruni K., Retno M., Dana A., and Bayu S., Cadangan Karbon Pada Berbagai Tipe Hutan Dan Jenis Tanaman Di Indonesia (2010)

3. FAO, State of The World's Forest 2016 (2016)

4. Ministry of Environment and Forestry Republic of Indonesia, The State of Indonesia's Forests 2018 (Ministry of Environment and Forestry, Republic of Indonesia, 2018)

5. B. Poulter, D. Frank, P. Ciais, R. B. Myneni, N. Andela, J. Bi, G. Broquet, J. G. Canadell, F. Chevallier, Y. Y. Liu, S. W. Running, S. Sitch, and G. R. van der Werf, Nature 509, 600 (2014)

6. R. T. Conant, Challenges and Opportunities for Carbon Sequestration in Grassland Systems:
A Technical Report on Grassland Management and Climate Change Mitigation (2010)

7. B. O. Andrade, C. Koch, I. I. Boldrini, E. VélezMartin, H. Hasenack, J.-M. Hermann, J. Kollmann, V. D. Pillar, and G. E. Overbeck, Nat. Conserv. 13, 95 (2015)

8. L. Ding, Z. Li, X. Wang, R. Yan, B. Shen, B. Chen, and X. Xin, Sensors 19, (2019)

9. O. Mutanga and A. K. Skidmore, Int. J. Remote Sens. 25, 3999 (2004)

10. T. Ontl and M. Janowiak, (2017)

11. O. E. Sala, F. S. Chapin, J. J. Armesto, E. Berlow, J. Bloomfield, R. Dirzo, E. Huber- Sanwald, L. F. Huenneke, R. B. Jackson, A. Kinzig, R. Leemans, D. M. Lodge, H. A. Mooney, M. Oesterheld, N. L. Poff, M. T. Sykes, B. H. Walker, M. Walker, and D. H. Wall, Science 287, 1770 (2000)

12. R. McEvoy, (2019)

13. T. Atsbha, A. Belayneh Desta, and T. Zewdu, Heliyon 5, e02329 (2019)

14. P. K. Ghosh and S. K. Mahanta, Range Manag. Agrofor. 35, 173 (2014)

15. A. D. Malik, K. Y. Z. Z. Dewa, P. Parikesit, S. Withaningsih, and R. Wingit, Biosaintifika J. Biol. Biol. Educ. 12, 111 (2020)

16. K. Hairiah, E. Andree, Rika Ratna Sari, and Subekti Rahayu, Pengukuran Cadangan Karbon : Dari Tingkat Lahan Ke Bentang Lahan : Petunjuk Praktis. Edisi Kedua (2011)

17. H. Weyerhauser and T. Tennigkeit, Forest Inventory and Monitoring Manual (2000)

18. K. T. Vashum, J. Ecosyst. Ecography 02, (2012)

19. A. E. Zanne, G. Lopez-Gonzalez, D. A. Coomes, J. Ilic, S. L. Lewis, R. B. Miller, N. G. Swenson, M. C. Wiemann, and J. Chave, (2009)

20. J. Chave, C. Andalo, S. Brown, M. A. Cairns, J. Q. Chambers, D. Eamus, H. Fölster, F. Fromard, N. Higuchi, T. Kira, J.-P. Lescure, B. W. Nelson, H. Ogawa, H. Puig, B. Riéra, and T. Yamakura, Oecologia 145, 87 (2005)

21. L. R. Khushi, M. Hossain, S. R. Abdullah, S. Saha, and M. R. H. Siddique, South. For. J. For. Sci. 81, 45 (2019)

22. G. K. Rasineni, A. Guha, and A. R. Reddy, Plant Sci. Int. J. Exp. Plant Biol. 181, 428

23. E. A. Ainsworth and A. Rogers, Plant Cell Environ. 30, 258 (2007)

24. L. J. Anderson, H. Maherali, H. B. Johnson, H. W. Polley, and R. B. Jackson, Glob. Change Biol. 7, 693 (2001)

25. P. A. Beedlow, D. T. Tingey, D. L. Phillips, W. E. Hogsett, and D. M. Olszyk, Front. Ecol. Environ. 2, 315 (2004)

26. A. B. Gebre, E. Birhane, G. Gebresamuel, K. M. Hadgu, and L. Norgrove, Agrofor. Syst. 93, 1191 (2019) 
27. D. Natalia, E. Arisoesilaningsih, and K. Hairiah, AGRIVITA J. Agric. Sci. 39, 74 (2016)

28. Z. Uthbah, E. Sudiana, and E. Yani, Scr. Biol. 4, 119 (2017)

29. M. Markum, E. Ariesoesiloningsih, D. Suprayogo, and K. Hairiah, AGRIVITA J. Agric. Sci. 35, 54 (2013)

30. B. A. Middleton and K. L. McKee, J. Ecol. 89, 818 (2001)

31. B. S. Acharya, J. Rasmussen, and J. Eriksen, Agric. Ecosyst. Environ. 153, 33 (2012)

32. P. K. R. Nair, B. M. Kumar, and V. D. Nair, J. Plant Nutr. Soil Sci. 172, 10 (2009)

33. V. Kumar, Nat. Environ. Pollut. Technol. 15, 365 (2016)F. De Lillo, F. Cecconi, G. Lacorata, A. Vulpiani, EPL, 84 (2008) 